\title{
Analysis of the Relationship Between School Heads' Leadership, Problem Solving and Critical Thinking Skills
}

\section{Şükrü Cankaya, European University of Lefke, TRNC \\ Oğuz Serin, European University of Lefke, TRNC}

\begin{abstract}
The aim of the study was to examine the relationship between the leadership, problem solving and critical thinking skills of the school heads who work at the educational institutions connected to the Ministry of National Education. The sample of the study consisted of 76 school heads in total, divided as \%39.5 females $(n=30)$ and $\% 60.5$ males $(n=46)$. The data of the study were collected by means of the Problem Solving Inventory (PSI), Leadership Inventory and Critical Thinking Inventory. The analysis of the data was carried out with the Correlation Test Technique. As a result of the study, it was found that there were significant relations between the leadership, problem solving and critical thinking skills of the school heads.
\end{abstract}

Keywords: Leadership, problem solving, critical thinking, school heads. 


\section{Introduction}

The most cricital role of both managment and its processes as to be successful is the leadership and its' implementors. Both the leadership and leader notions are the most frequent studied notions throughout the history. The reason of this is that we face with these two notions continually in every division in life (Avc1, 2015). According to Baltas (2012), the leader is the one who set a good sample to the surrounding with his/her behaviour pattern, style and values. The leader presents an assimilative model to the others who are subordinate to him/her. The increasment demands upon the change and development in the educational organizations leads to the interest to the ladership notion within the context of school (Keith, 2009). According to Kotter, leadership and leader notions are different as well when regarding their own principles. While the administrative principles of the adminitrator are classified as; planning and pricing, organization and workers, control and problem solving ; the leader's administrative principles are categorized as : identifing the principles that provides the process of the organization, providing the participation when taking decision of the workers, the motivation of the workers for common aims (Nelson ve Quick, 2005). The behaviour pattern of leaders has a significative role in the embodiment of the organization culture (Buluç, 2013; Schein, 2010). Schools are either differen from each other or similar with each other in terms of their organization in every country of the world and they all have some targets as well as functions. The main expectation from schools is an ultimate perfomance when it comes to their targets and functions (Sisman, 2002). The education principals have to plan and turn it to apply the changes as a process in order to create an effective education system (Karip ve Köksal, 1996). School directors have to comply with the changing community structure. Unless a school welcomes the expectations of the community, no achievement will be at stake (Drucker, 2012). The role of the school directors in diagnosing and solving problem is directly associated with the leadership realization (Hallinger, 1992). The school directors should think strategically and perform leadership behaviour pattern rather than linear thinking or monotype leadership behavior pattern (Pisapia ve Pang, 2009).

According to Celik (2004), the director is the one who coordinates the organizational aims of the workers in line with the effectuation of the organizational targets. The leader, on the other hand, is qualified as the one who affect the group members. 
If the education leaders are well-informed and sophisticated, they might determine the broad politics oriented to the targets and they may step in the tools as to make them real (Bursalioglu, 2008).

When the literature was examined in Turkey of late years, many studies were encountered related with the leadership characteristics as well as their related variables. Leaderhip styles (Avc1,2015); leadership standarts Ahi, 2011); leadership manners (Dasc1, 2014); leadership and organizational commitment (Sama ve Kolamaz,2011); leadership standarts (Köksal,2011), leadership roles of the school directors (Tahaoglu ve Gedikoglu, 2009); exhaustion of the leadership and teachers (Cerit, 2008); learning organization with the leadership styles of the school directors (Korkmaz, 2008); leadership and organizational dependence (Buluc, 2009), leadership behaviours, administrator and teacher opinions (Ozdemir, Sezgin ve K1lic, 2015), educational leadership and school culture (Sahin, 2006; 2011); organizational motivation (Cetinkanat, 2000). Some studies related to the leadership which were carried out in abroad were encountered. Campbell, Corbally ve Nystrand, 1983; Hersey, Blanchard ve Johnson, 1996;Leithwood ve Jantzi, 2006.; Bass, 1990; Kotter, 2001; Nelson ve Quick, 2005; Owen, Hodgson ve Gazzard 2011). However, there could not be found any studies that were handled togethet related with the leadership, problem solving and critical thinking of school heads. Administration process can be explained as a problem solving process while the main duty of the administrators can be defined as problem solving (Güclü, 2003). It is mainly expected the administrators to use school resources efficiently, be consistent regarding the relationships at school, make students' achievement level higher, deal with organizational problems, manage conflictions, have vision, motivate personnel, take valid and reliable decisions and have the capacity to solve problems (Çelikten, 2001). According to Kücükahmet (2000), problems develop the education system and they are the driving power of the education system. For this reason, thinking about the education system without problems is hard. So, dealing with every kind of problems is very crucial. The administrators should be well- equipped. According to Hoy and Miskel (1987), solving problem is the main responsibility of the administrators. All of the school heads should know the importance of the problem solving process as school administration is mainly related with the problem solving process. Thus, school administrators should comprehend or know the organizational problems throughly and provide some solution suggestions. School administrators can be successful as long as they can take efficient and objective decisions. It 
is needed the school administrators to make a choice among from other multi different choices and produce the best solution. For these, the problem solving ability is required to be pretty good (Güclü, 2003). The contemporary understanding is also perceived as 'probem solver'. When viewed from this aspect, it can be said that management is an art of solving a problem. The most strategic part of the education system and school management is the school administrator (Kocaoglu, 1992). In the related literature, some of studies related with the problem solving abilities of the school heads were faced with. Some of these are, Kocak and Eves,2010; Ada,Dilekmen, Alver and Secer, 2010; Iskender,Yaman and Akbayrak, 2004; Akca and Yaman, 2009; Güclü, 2000). Currently, critical thinking is the main ability in all of occupational groups. Critical thinking is not a choice to be used in education process but an indivisible part of education. This is because of the critical thinking which is required to be well educated (Norris, 1985). For so long, educators accept that critical thinking is an important and terminal product of the education. Thinking undependently and subjectively are among the important notions that describes the meaning of critical thinking. The person who thinks critically does not accept others' opinion and remarks inactively but he/she analyses another opinion and remarks as to create their own thoughts. This self-dependence liberates the person's mind, heart and acts (Doganay ve Unal, 2006). Ennis (1989), who have lots of studies connected to critical thinking, defines the meaning of critical thinking as reasonable and reflective thinking when taking decisions concerned doing what and believing what (Arslantaş and Kurnaz, 2015). When we evaluate the different definiton and approaches related with critical thinking, it is possible to reach some common points. First of all, critical thinking is a thinking process that includes knowledge, strategy, ability and attitudes (Doğanay and Unal , 2006): In Turkey, within the frame of 2017 targets, it is aimed the enlightened people, who are wanted to be educated, to be equipped with some abilities such as: creativity, being reflective, having critical thinking and problem solving ability as well as high level mental abilities. Being equipped with some high-level abilities as to produce information and technologies in order to contribute country's development and competing with colleagues in an international level are mandatory for all of the careerists (Arslantas and Kurnaz, 2015). In Turkey, most of the dissertations related with thinking are performed oriented to the university and primary education students. Teachers and nurseries are mostly participants as occupational groups during dissertations (Arslantas ve Kurnaz, 2015). There are a few studies performed with the school administrators in the field of education management. The relation between the critical thinking liabilities and classroom management 
sufficiency of the school administrators (Tuncer, 2015) ; relation between critical thinking liabilities and classroom management sufficiency perception of the classroom teachers (Güner,2010); explanatory relationship pattern between creative thinking, problem solving abilities and critical thinking liabilities of the classroom teachers with their constructivist attribute (Turan,2010). Critical thinking in education (Kazanc1, 1989). As is seen, there are very few studies handled critical thinking abilities of school administrators in Turkey.

In this regard, when related literature was examined, no studies related with the leadership, problem solving and critical thinking abilities of the school heads or school assistant managers who worked at primary or secondary education schools, connected to the Ministry of National Education in Turkish Republic of Northern and Cyprus were faced with.So it is claimed that the results of this study will contribute to this field.

\section{Aim of the Study}

The aim of the study was to examine the relationship between the leadership, problem solving and critical thinking skills of the school heads who work at the educational institutions connected to the Ministry of National Education.

Answers to the question were asked for as to achieve this goal :

1. Is there a significant relation between leadership, problem solving and critical thinking skills of the school administrators?

\section{Methods}

\section{Research Design}

The present research used a descriptive kind of general survey model with a quantitative method. Widely used, the descriptive approach aims to identify the condition of interest. Survey models refered to research approaches that aimed to describe past or existing situations. The situation, event, individual, or object related to the study was used to determine their own terms (Karasar, 2009).

\section{Population and Sample}


As study population, principals and vice principals, who took part at education institutions and connected to the Ministry of National Education in TRNC was chosen. In total, 76 school administrators constituted the study sample which is determined with the quota sampling method as \%39,5 women $(n=30)$ and \%60,5 $(n=46)$ men.

\section{Research Instruments}

Critical Thinking Skill Evaluation Scale: As a data collection instrument developed by Yoldaş (2009), Cronbach's alpha reliability coefficient of .87 with "Critical Thinking Skills Scale" was developed by the researcher and the "Personal Data Form" was used. The "Critical Thinking Skills Scale" of sensibility in critical thinking, consciousness in critical thinking, empathy in critical thinking, adoption in critical thinking, assumptions in critical thinking, common sense in critical thinking, and critical thinking skills in media had a total of 42 items and 7 sub-dimensions; $45.14 \%$ of the total variance out of 7 sub-factors was explained. In this study, the Cronbach's alpha reliability coefficient was calculated as 0.80 . The range score of the scale was between 42 and 210. The average scores for the critical thinking skills scale were as follows: low scores $(\bar{x}=42-98)$, moderate $(\bar{x}=99-154)$, and high $(\bar{x}=155-210)$ defined as a 3-point range. Higher scores indicated positive critical thinking skills; lower scores indicated negative critical thinking skills.

Problem Solving Inventory (PSI): Problem Solving Inventory was used which was developed by Heppner and Petersen (1982), applied to Turkish by N.Sahin, N.H.Sahin and P.P.Hepner (1993) and performed validity and reliablity .The scale ,determined as ".90" of the Cronbach's Alpha internal consistency coefficient, was determined as ".87" for this study.

Leadership Inventory: Validity and reliability study was performed which was developed by Bass and Auolio (1993) and applied to Turkish by Korkmaz (2005) The reliability level of the Turkish form of study was found as 0.88. 5 factors were included in the scale. It was interpreted as: from which factor a high score was taken, the person had the charasteristics of the leadership.

\section{Data Analysis:}

As to find if there was any relation between the applied scales and sub-dimensions and if there was any, as to find out the way of the relation "Pearson Product-Moment Correlation Coefficient" analysis was used. 


\section{Findings}

In this section, the relations betwen leadership, problem solving and critical thinking skills of the school administrators in TRNC who took part in both primary and secondary education schools were handled.

As seen from the table 1, from the interactionist leadership characteristics as being from the sub- dimensions of the leadership inventory, between the "fully free administration style" with "administration according to the expectations"' $\mathrm{r}=.487 ; \mathrm{P}<.001)$ and " fully free administration style" with "administration according to exemptions"' $(\mathrm{r}=.476 ; \mathrm{P}<.001)$, a positive significat relation was found. From transformist leadership charasteristics; a high level of a positive significant relation between "charisma" with intellectual stimulation and intellectual support $(\mathrm{r}=.866 ; \mathrm{P}<.001)$ was found.

Between problem solving skill with interactionist leadership characteristics $(\mathrm{r}=-.405 ; \mathrm{P}<$ .001) a negative relation; between "problem solving skill" with "charisma"' $\mathrm{r}=.479 ; \mathrm{P}<$ $.001)$ and problem solving with intellectual stimulation and individual support ( $\mathrm{r}=.336 ; \mathrm{P}<$ $.001)$, a positive significant relation was determined.

Between critical thinking skill with freely administration style $(\mathrm{r}=.428 ; \mathrm{P}<.001)$ a negative relation; between critical thinking with problem solution, on the other hand $(r=.715$; $\mathrm{P}<$ .001 ), a high level significant relation was found.

Table 1: Pearson Product-Moment Correlation Coefficient Analysis Results Related to the leadership, problem solving and critical thinking skills of the school administrators

\begin{tabular}{|c|c|c|c|c|c|c|c|}
\hline & & $\begin{array}{c}\text { Fully free } \\
\text { administra- } \\
\text { tion style }\end{array}$ & $\begin{array}{l}\text { Administration } \\
\text { (active) according } \\
\text { to the expectations }\end{array}$ & $\begin{array}{l}\text { Administratio } \\
\text { n (inactive) } \\
\text { according to } \\
\text { the } \\
\text { exemptions }\end{array}$ & charisma & $\begin{array}{c}\text { Intellectual } \\
\text { stimultion } \\
\text { and } \\
\text { individual } \\
\text { support }\end{array}$ & PSI \\
\hline \multirow{3}{*}{$\begin{array}{l}\text { Fully free } \\
\text { administrat } \\
\text { ion style }\end{array}$} & $\begin{array}{l}\text { Pearson } \\
\text { Correlation }\end{array}$ & \multirow{3}{*}{-} & & & & & \\
\hline & $\begin{array}{l}\text { Sig. (2- } \\
\text { tailed) }\end{array}$ & & & & & & \\
\hline & $\mathrm{N}$ & & & & & & \\
\hline \multirow{2}{*}{$\begin{array}{l}\text { Administra } \\
\text { tion } \\
\text { (active) }\end{array}$} & $\begin{array}{l}\text { Pearson } \\
\text { Correlation }\end{array}$ &, $487(* *)$ & \multirow[t]{2}{*}{ - } & & & & \\
\hline & Sig. (2- & ,000 & & & & & \\
\hline
\end{tabular}




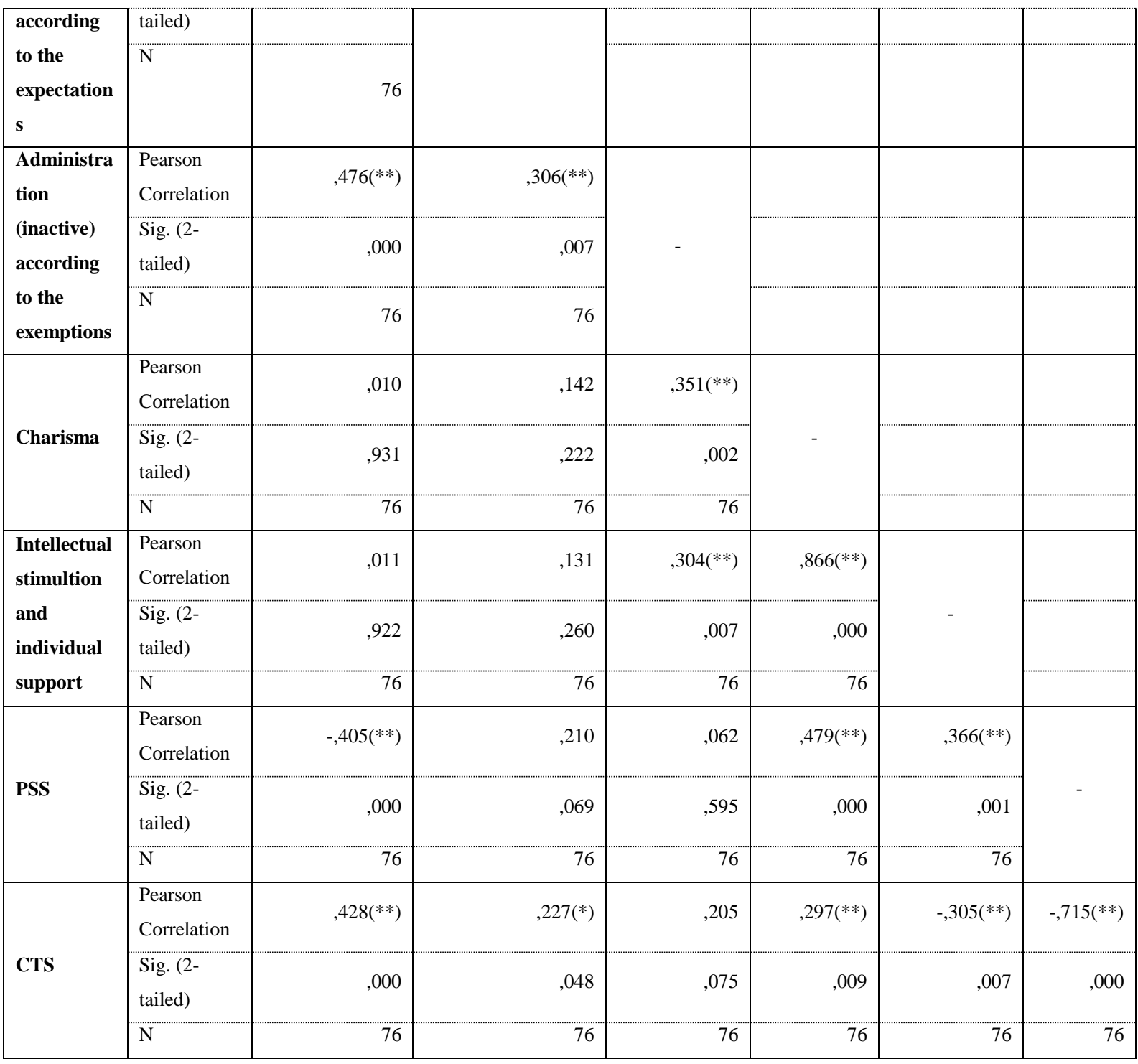

** Correlation is significant at the 0.01 level (2-tailed).

* Correlation is significant at the 0.05 level (2-tailed).

PSS: Problem Solving Skill

CTS: Critical Thinking Skill

\section{Discussion and Interpretation}

When examining the results of the study in general, the relationship regarding leadership characteristics of the school administrators who were included into the sampling group was studied. A positive significant relation was found between "fully free administration" with "administration according to expectations" and " administration according to exemptions" which were all from the characteristics of interactionist leadership characteristics. From the 
transformational leadership characteristics, a high level positive significant relationship between "charisma" with intellectual stimulation and individual support was determined.

In this case, the positive result concerning the relation between fully free administration, administration according to expectations and administration according to exemptions as well as charisma with intellectual stimulation and individual support which were from the characteristics of transformational leadership, was expected to be found. The school principals and deputy principals took part in TRNC education institutions had the capacity to solve problem and think critically more than the ones who had interactionist leadership speciality.There could be found some study results which reveal that the school administrators who adopted transformational leadership style as to prepare an atmosphere with the aim of generating a school culture in which individual achievement was at high level as well as in which organizational citizenship manner was performed on part of the workers; Leithwood ve Jantazi, 2006; Bogler, 2001; DiPaola ve Hoy, 2005; Akt:Avc1, 2015). Negative relation between " problem solution skills" with "fully free administration leadership style"from the characteristics of transformational leadership characteristics. In this case, the school principals' (who adopt fully free administration style) problem solution skills were decreasing.

A positive high-level relationship between "problem solving skills" of the school administrators with "charisma" which was from the characteristics of transformational leadership and "intellectual stimulation" was found.This result is pretty important in terms of the school administrators who have transformational leadership characteristics as it showed that the problem solving skills of the administrators were in high-level.It was found that between the school administrators who adopt "fully free administration" style which was from the characteristics of interactionist leadership characteristics and "critical thinking skills", there was aback relationship. According to this, it was determined that the school administrators who adopted the style of fully free adminisration style had less critical thinking skills.

Administration process is defined as solving problem process while the duty of the administrator is explained as solving problems (Güclü, 2003). School head is primarily responsible from the school and administration of the school program in addition to the 
education and achievement of the school (Sisman, 2012).Herein, the leadership characteristics of the school head is crucial. In this sense, the importance of the leadership styles of the school heads is obvious as the styles lead to a proper school culture or atmosphere and reach the organizational targets of the school (Korkmaz, 2008). Robbins, Decenzo and Coulter (2013) define the administration term as performing a duty with other people or by means of other people in order to be able to carry out the duty in an effective and affective way. Problem recognition and solving role of the school administrators is directly related with carrying out the leadersip role (Hallinger, 1992).A high level positive significant relationship between critical thinking and problem solving skills of the school administrators was found. This result was expected. The school administrators who have problem solving skills use their critical thinking skill more. A positive significant relationship between critical thinking and problem solving skills was found. Critical thinking is now the main skill in all occupational groups. In all occupational groups, having active thinking skills and critical thinking skills is very improtant (Arslantaş ve Kurnaz, 2015). The critical thinking skills of the school principals and deputy principlas whose problem solving skills were perceived as high were found at high level. Problem solving method is a hinking and applying way which is related with understanding problem and defining it, creating a hypothetical solving way and trying this problem solving method until the verification (Oguzkan, 1993). It is expected the individuals to be creative and think critically as to find effective solutions to different problems in an ctive way (Sesli,2013). According to Hoy and Miskel (1987), problem solving is the main responsibility of all of the administrators. It is required the administrators to know the importance of problem solving process as the school administration is directly related with the problem solving process. Watson and Glaser (1964) define critical thinking as a general process which includes the acts such as problem solving, studying and researching.

\section{Result and Suggestions}

Between "fully free administration style" which was from the interactionist leadership characteristics, with "administration according to expectations" and " administraton according to exemptions", a positive significant relation was found. From the leadership inventory sub dimensions and from the transformational leadership characteristics, between “ charisma" with intellectual stimulation and individual support, a high level significant relation was detected. Between problem solving skill and fully free admininstration which was from interactionist leadership characteristics, on the other hand, a negative oriented 
significant relation ; with "problem solving skill " and "charisma" which was from the characteristics of transformational leadership a positive significant relation was found. Between critical thinking skill with fully free administration style a negative relation; between critical thinking with problem solving a high level significant relation were found.

\section{Suggestions}

Some suggestions were presented for this study. Positive oriented relations between problem solving and critical thinking skills were found at the end of this study which evaluates the school principals and deputy principals who took part in TRNC education institutitons. Some activities and on-the- job educations should have been organized such as administration courses, conferences, seminars or panels with the aim of improving the skills of an active problem solving skill, being creative and thinking critically. School principals and deputy principals should have come together at certain times as to share their experiences upon their positive problem solving skills and critical/ creative thinking skills . This study's results could be generalized to the sampling group to which the study was performed. The same study could be performed with a wider sampling group and different variables. 


\section{References}

Ada, S., Dilekmen, M., Alver, B., \& Secer, İ. (2010). ilk ve ortaögretim okul yöneticilerinin problem çözme becerilerinin çesitli degiskenler açısından incelenmesi. Kuram ve Uygulamada Egitim Yönetimi [Educational Administration: Theory and Practice], 16(2), 153-166.

Ahi, B. (2011). İlköğretim okul müdürlerinin sahip olduğu liderlik standartlarının öğretmen görüşlerine göre değerlendirilmesi.Yayımlanmamış Yüksek lisans Tezi, Gazi Üniversitesi Eğitim Bilimleri Enstitüsü, Ankara.

Arslantaş, S., ve Kurnaz, A. (2015). Konu Başlığında 'Eleştirel Düşünme’ Kavramı Geçen, Yök Veri Tabanına Kayıtlı Yüksek Lisans Ve Doktora Tezlerinin Farklı Değişkenlere Göre Sınıflandırılması.ISCAT, Sakarya.

Avcı, A. (2015). Öğretmen algılarına göre okul müdürlerinin liderlik stilleri. Hasan Ali YücelEğitim Fakültesi Dergisi Cilt: 12-2, Sayl: 24, 2015-2, s.161-189

Baltaş, A. (2012). Türk kültüründe yönetmek: Yerel değerlerle küresel başarllar kazanmak. İstanbul: Remzi Yayınevi.

Buluç, B. (2013). Örgüt kültürü ve iklimi. S. Özdemir (Ed.), Eğitim yönetiminde kuram ve uygulama içinde (ss. 101-130). Ankara: PegemA.

Bursalığlu, Z. (2008). Okul yönetiminde yeni yapı ve davranış. (14. Basım). Ankara: Pegem A Yayınc1lık.

Campbell, R., F., Corbally, J., E. And Nystrand, R., O. (1983). Introduction to educational administration. (Sixth edition). Massachusetts: Allyn and Bacon.

Cerit, Y. (2008). İlköğretim okulu müdürlerinin hizmet yönelimli liderlik davranışlarının öğretmenlerin tükenmişliklerine etkisi. Kuram ve Uygulamada Ĕ̆itim Yönetimi [Educational Administration: Theory and Practice], 55, 457-570.

Çelik, V. (2004). Liderlik: Ĕ̈itim ve okul yöneticiliği el kitabı. Y. Özden (Ed). Ankara:PegemA.

Çelikten, M. (2001), “Okul Yöneticilerinin Problem Çözme Becerileri”, Kuram ve UygulamadaĔ̈itim Yönetimi, 27: 297-309.

Çetinkanat, C. (2000), Örgütlerde Güdülenme ve Işs Doyumu, Anı Yayınc1lık, Ankara.

Daşç1, E.(2014). il̇köğretim kurumu yöneticilerinin liderlik tarzları ile öğretmenlerin yaşadıkları yıldırma (mobbıng) ve örgütsel sessizlik davranışları arasındaki ilişki. Yayımlanmamış Yüksek lisans Tezi, Gazi Üniversitesi Eğitim Bilimleri Enstitüsü, Ankara. 
Demir, M. K. (2006). İlköğretim Dördüncü Ve Beşinci Sınıf Öğrencilerinin Sosyal Bilgiler

Dersinde Eleştirel Düşünme Düzeylerinin Çeşitli Değişkenler Açısından İncelenmesi.Ankara, GaziÜniversitesi, EğitimBilimleriEnstitüsü (yayımlanmamışdoktoratezi).

Doğanay, Ahmet, and F. Ünal (2006). Eleştirel Düşünmenin Öğretimi. İçerik Türlerine Dayalı Öğretim. Editör: A. Şimşek) Ankara: Nobel Yayıncılık.

Drucker, P. F. (2012). Kendini yönetmek (Çev.İnan, M.). Esaslar: Harvard Business Review'den en kalıc yönetim fikirleri. İstanbul:Optimist Yayınları.

Güçlü, N. (2003). Lise müdürlerinin problem çözme becerileri. Milli Egitim Dergisi, 160, 272-300.

Güner, Ö.(2010).Sınıf öğretmenlerinin eleştirel düşünme eğilimleri ile sınıf yönetimi yeterliliği algıları arasındaki ilişki. Yayımlanmamış yüksek lisans tezi.

Hallinger, P. (1992). The evolving role of American principals: From managerial to instructional to transformational leaders. Journal of Educational Administration, $30(3), 35-48$.

Hersey, P., Blanchard, K., H. and Johnson, D., E. (1996). Management of organizational behavior. utilizing human resources. (Seventh edition). New Jersey: Prentice-Hall Inc.

Hoy, W.K. ve Miskel, C. G. (1987). Educational Administration-Theory, Research and Practice. USA: Random House.

İskender, M., Yaman, E., Albayrak, G. (2004). İlköğretim okullarında etkin yöneticiler için bir gösterge: problem çözme becerisi.M.Ü. Atatürk Eğitim Fakültesi Eğitim Bilimleri Dergis. Sayı 20, Sayfa : 73-84

Karip, E. ve Köksal, K. (1996). Etkili eğitim sistemlerinin geliştirilmesi. Kuram ve Uygulamada Ĕgitim Yönetimi, 6:245-258

Kazanc1, O. (1989). EğitimdeEleştiriciDüşünme v eÖğretimi.İstanbul: KazancıKitapAş.

Keith, J. A. (2009). Perceptions of school leadership capacity and student achievement

(Doctoral dissertation). Retrieved from ProQuest Dissertations and Thesis database. (UMI No. 3371746)

Kocaoğlu, A. (1992). İlköğretim Okulu Müdürlerinin Yeterlikleri. Yayımlanmamış yüksek lisans tezi, TODAİE, Ankara.

Koçak, R., Eves, S (2010). Okul yöneticilerinin iş doyumları ile problem çözme becerileri arasındaki ilişkiUluslararası İnsan Bilimleri Dergisi.

Kotter, J. P. (2001). What leaders really do? Harvard Business Review, 79(11), 85-96. 
Korkmaz, M. (2008). Okul müdürlerinin liderlik stilleri ile öğrenen örgüt özellikleri arasındaki ilişki üzerine nicel bir araştırma. Kuram ve Uygulamada Eğitim Yönetimi [Educational Administration: Theory and Practice], 53, 75-98.

Leithwood, K., \& Jantzi, D. (2006). Transformational school leadership for large-scale reform: Effects on students, teachers, and their classroom practices. School Effectiveness and School Improvement, 17(2), 201-227.

Nelson, D., L. and Quick, J., C. (2005). Understanding organizational behavior. (Twice edition). Ohio: Thomson South-Western.

Norris, S. (1985). Synthesis of research on critical thinking. Educational Leadership, 42, 4045.

Oğuzkan, A. F. (1993). Eğitim Terimleri Sözlüğü. Ankara: Emel Matbaacılık.

Özdemir, S., Sezgin, F. ve Kılıç, D. O. (2015). Okul yöneticisi ve öğretmen görüşlerine göre okul yöneticilerinin liderlik yeterlikleri. Eğitim ve Bilim, 177, 365-383.

Owen, H., \& Hodgson, V., \& Gazzard N. (2011). Liderlik elkitabı (Çev. Çelik, M.). İstanbul:Optimist Yayınları.

Pisapia, J., \& Pang, S. K. (2009). Rethinking leadership: New tactics for a globalizing world. Paper presented at the Global Leadership Forum, September 6, Istanbul, Turkey.

Robbins, S. P., \& Decenzo, D. A., \& Coulter, M. (2013). Yönetimin esasları (Çev. Öğüt, A.) Ankara:Nobel Yayınları.

Sesli,S.(2013).Okul Öncesi Öğretmenlerinin Problem Çözme Becerileri ile Disiplin Anlayışlarının İncelenmesi.Yüksek Lisans Tezi .Eğitimbilimleri Enstitüsü.Erciyes Üniversitesi. Kayseri.

Şahin, S. (2006). İlköğretim okulu müdürlerinin dönüşümcü ve sürdürümcü liderlik stilleri (İzmir ili örneği). Eurasian Journal of Educational Research, 23, 188-199.

Şahin, S. (2011). Öğretimsel liderlik ve okul kültürü arasındaki ilişki (İzmir ili örneği). Kuram ve Uygulamada Ĕgitim Bilimleri (Educational Sciences: Theory\&Practice), 11(4), 1909-1928.

Şama, E., ve Kolamaz,C.(2011). Destekleyici ve geliştirici liderlik özellikleri ile örgütsel bağlılık arasındaki ilişki. Türk Ĕgitim Bilimleri Dergisi Bahar 2011, 9(2), 313-342 Schein, E. H. (2010). Organizational culture and leadership. San Francisco: Jossey-Bass. Şişman, M. (2012). Öğretim liderliği. Ankara: Pegem A. Yayınları, 4. Basım. 
Online Journal of Communication and Media Technologies Volume: 8 - Issue: 1 January - 2018

Turan,H. (2010). Sınıf öğretmenlerinin yapılandırmacı özellikleri ile yaratıcı düşünme, problem çözme becerileri ve eleştirel düşünme eğilimleri arasındaki açıklayıcı ilişkiler örüntüsü. Yayımlanmamış Doktora Tezi

Watson, G. (1964), Watson, G. Glaser, E. Critical thinking appraisal manual. Harcourt, Brace\& World, New York; 1964. 